\title{
High stearic sunflower oil: Latest advances and applications ${ }^{\text {is }}$
}

\author{
Joaquín J. Salas*, Miguel A. Bootello, Enrique Martínez-Force, Mónica Venegas Calerón \\ and Rafael Garcés \\ Instituto de la Grasa (CSIC), Ctra. Utrera Km. 1, Building 46, 41013 Sevilla, Spain
}

Received 24 March 2021 - Accepted 27 May 2021

\begin{abstract}
Regular sunflower oil is rich in linoleic acid. To improve its properties for different applications several genotypes with modified fatty acid compositions have been developed. Amongst them, the most remarkable have been high oleic and high stearic types. High stearic sunflower lines reported to date have been produced by traditional methods of breeding and mutagenesis. The mutations affected the expression of enzymes responsible for stearate desaturation in developing seeds. This trait has been combined with standard and high oleic backgrounds, giving high stearic lines with high contents of linoleic or oleic acids and thus different physical properties, increasing their functionality and potential applications. Nevertheless, for applications requiring plastic or confectionery fats, the oils have to be fractionated to obtain derived fats and butters with higher levels of solids. In the present review we present recent advances for the above mentioned topics related to high stearic sunflower oils.
\end{abstract}

Keywords: Helianthus annuus / sunflower oil / high stearic sunflower / oil fractionation / high stearic sunflower stearins

Résumé - Huile de tournesol à haute teneur en acide stéarique : dernières avancées et applications. L'huile de tournesol conventionnelle est riche en acide linoléique. Afin d'améliorer ses propriétés pour différentes applications, plusieurs génotypes avec des compositions d'acides gras modifiées ont été développés. Parmi eux, les plus remarquables ont été ceux à haute teneur en acide oléique et en acide stéarique. Les lignées de tournesol à haute teneur en acide stéarique rapportées à ce jour ont été produites par des méthodes traditionnelles de sélection et de mutagenèse. Les mutations ont affecté l'expression des enzymes responsables de la désaturation des stéarates dans les graines en développement. Ce trait a été introduit dans des lignées conventionnelles et à haute teneur en acide oléique, donnant du matériel à haute teneur en stéarate avec des teneurs élevées en acides linoléique ou oléique et donc des propriétés physiques différentes, augmentant leur fonctionnalité et leurs applications potentielles. Néanmoins, pour les applications nécessitant des graisses plastiques ou de confiserie, les huiles doivent être fractionnées pour obtenir des graisses et des beurres dérivés avec des niveaux plus élevés de solides. Dans cette revue, nous présentons les avancées récentes concernant les sujets mentionnés ci-dessus liés aux huiles de tournesol à haute teneur en stéarique.

Mots clés : Helianthus annuus / huile de tournesol / tournesol à haute teneur en acide stéarique / fractionnement de l'huile / stéarines de tournesol à haute teneur en acide stéarique

\section{Introduction}

Vegetable oils are an important source of lipids for the human diet, providing also important nutrients like tocopherols and other fat-soluble vitamins (Subar et al., 1998; FAO/WHO, 2002). From a technical point of view, fats and oils are important in the formulation and processing of many food products as primary or secondary components (Gunstone, 2009) or providing the medium in which the food is cooked by frying for example (Parkash Kochhar and Gertz, 2004). Vegetable oils are extracted from oil crops, which accumulate triacylglycerols (TAG) in their seeds or fruits. The oils are extracted by different processes that vary according to source. The resulting crude oils are then refined, removing impurities and anti-nutritional components to make them suitable for human intake. Sunflower oil is extracted from seeds, more strictly achenes (dry fruit) which are produced on the sunflower capitulum. These seeds accumulate oil in the

\footnotetext{
मे Contribution to the Topical Issue "Creating new oil \& protein crop value chains / Construire de nouvelles filières oléoprotéagineuses".

*Correspondence: jjsalas@ig.csic.es
} 
cotyledons (or kernel) that develop within a ligneous pericarp or hull (Bockisch, 2015). Sunflower yields a high quality oil that is highly appreciated by consumers. Regular sunflower oil is rich in linoleic and oleic fatty acids, the relative proportions of which change with growing location and temperatures (Salas et al., 2015). This crop is produced mostly in temperate countries and is the third annual oil crop produced in the world after soybean and rapeseed (FAO, 2020). Sunflower oil can be easily extracted by a combination of physical and solvent methods (Le Clef and Kemper, 2015). Then it is refined in a process involving degumming, neutralization, bleaching, deodorization and clarification by winterization (Dijstra, 2015). The resulting oil is highly transparent and has a mild smell and aroma. The most common applications of regular sunflower oil are retailing, frying and elaboration of sauces and emulsions (Salas et al., 2015). Although the tocopherols present in sunflower oil confer some extra oxidative stability to this oil, its high levels of linoleic acid make regular sunflower oil more unstable at high temperatures or during long periods of storage than other oils like peanut or olive (Martín-Polvillo et al., 2004). The oxidative performance of regular sunflower oil is clearly surpassed by high oleic sunflower, which was developed from a mutant found and reported by Soldatov (1976). This mutant displays a much higher content of oleic acid, which ranges from 70 to $90 \%$ at the expense of linoleic acid. High oleic is a semidominant trait caused by a duplication of the $\Delta 12$ desaturase gene responsible for synthesis of linoleate from oleate in the endoplasmic reticulum of developing seeds. This mutation decreased activity of this enzyme in sunflower tissues (Fernández-Martínez et al., 1989; Sperling et al., 1990; Hongtrakul et al., 1998), affecting only gene expression but not gene functionality (Martínez-Rivas et al., 2001). The Pervenets mutation have been object of extensive research, being mapped and characterized by Lacombe and Bervillé (2001), who reported a tight genetic linkage with one of the oleate desaturase genes present in sunflower. Later studies demonstrated mechanisms causing the gene silencing (Lacombe et al., 2002a) and e segregation of the mutation in further generations (Lacombe et al., 2002b). Other high oleic sunflower mutants have been recently reported, for example one carrying the mutation named 29066 or NM1, which showed higher stability and reduced influence of genetic background. This mutant was less affected by environmental factors and the mutation was proved to be more effective to produce ultra-high oleic lines (Alberio et al., 2018).

The high oleic trait has been transferred to commercial hybrids and high oleic sunflower is produced all over the world, being one of the first oil crops commercialized with modified fatty acid composition together with erucic acid free oilseed rape or canola. The useful properties and healthy fatty acid composition of this oil have made it widely accepted by all types of consumers. Moreover, modifications of the initial phenotype have also emerged, such as mid-oleic or Nusun sunflower oils (Kleingartner, 2002).

\section{Vegetable fats and alternatives}

Despite the interesting properties and performance of regular and high oleic sunflower oils, they are liquid vegetable oils due to their fatty acid composition. This fact limits their applications when more solids are required. Thus, many food formulations require addition of plastic or confectionery fats to reach their proper consistence or texture (Ghotra et al., 2002; Talbot, 2009). The solid content of a fat at a given temperature largely depends on its saturated fatty acid content and composition. In the past, the fats used for solid formulations usually came from animal sources, tropical species or were produced from liquid vegetable oils by partial hydrogenation. However, industrial use of animal and partially hydrogenated fats has declined in recent years as to they are not recommended in a healthy diet. In addition, animal fats can pose problems in global distribution due to religious dietary restrictions (halal and kosher food). Therefore, most solid or structured fats used by food industry now come from tropical plant species, especially coconut, and oil palm (Traitler and Dieffenbacher, 1985). There has been an extraordinary growth of palm oil production in the last decades. This crop produces oil rich in palmitic and oleic acids and can be sequentially fractionated to produce liquid oils (oleins) plus solid stearins with higher contents of solids (Kellens et al., 2007). The level of solids and the melting curve of fats derived from palm or from other source can be also modulated through reactions of randomization or interesterification (chemically or enzymatically), which thus increases the variety of lipids available for food formulation on the market (Zhang et al., 2020). Confectionery fats are those used for the elaboration of chocolates, coatings and in general products requiring fats with a solid brittle butter or fat. The fat most commonly used in this products is cocoa butter (Smith, 2021). However, in recent years, other fats have been used as an alternative. These are cocoa butter equivalents (CBEs), which are fats with the same melting profile and crystallization pattern as cocoa butter, and so compatible with this fat in any proportion (Smith, 2001). CBEs are made from tropical butters rich in stearate, like shea butter stearins, combined with other fats such as palm mid fractions. Summarizing, the production of solid, plastic and structured fats is at present dependent on the supply of tropical fats, with special mention for palm oil due to its volume of production.

\section{High stearic sunflower}

Although the total replacement of the palm oil in food industry is an unrealistic objective today, there is plenty of room for new alternative fats, that should be versatile, healthy and sustainable, as well as economically affordable. Sunflower mutagenesis programs started about 1990 had the production of solid alternative fats as their main objective. These programs applied methods of chemical or radiation mutagenesis to sunflower populations that were then propagated and screened using the non-destructive half-seed method. The result of this research was a collection of sunflower mutants with altered fatty acid composition including, in particular, several with highly saturated phenotypes (Osorio et al., 1995; Fernández-Martínez et al., 1997). The most promising mutant was the high stearic sunflower or CAS-3. This genotype accumulated oil with up to $25 \%$ stearic acid (Tab. 1), a high melting point fatty acid providing higher levels of solids than palmitic at equal concentrations. Furthermore, although stearic is a saturated fatty acid, its intake does not increase 
Table 1. Typical composition of different oils and fractions mentioned in this study. Sunflower hard stearin was prepared by solvent fractionation of CAS-15. The sunflower soft stearin was obtained by dry fractionation of the same oil.

\begin{tabular}{|c|c|c|c|c|c|c|c|c|c|c|c|c|}
\hline \multirow[t]{2}{*}{ Oil or fraction } & \multicolumn{10}{|c|}{ Composition (\%) } & \multirow{2}{*}{$\begin{array}{l}\text { Total } \\
\text { saturated } \\
(\%)\end{array}$} & \multirow{2}{*}{$\begin{array}{l}\text { Atherogenicity } \\
\text { index }\end{array}$} \\
\hline & $\mathrm{C} 6-\mathrm{C} 10$ & $12: 0$ & $14: 0$ & $16: 0$ & $16: 1$ & 18:0 & $18: 1$ & $18: 2$ & $20: 0$ & $22: 0$ & & \\
\hline CAS $-3^{1}$ & & & & 7.2 & & 26.3 & 18.6 & 45.1 & 1.4 & 1.4 & 36.3 & 0.11 \\
\hline CAS $-15^{2}$ & & & & 4.3 & & 16.5 & 70.6 & 5.2 & 1.3 & 2.1 & 24.2 & 0.06 \\
\hline Palm kernel ${ }^{3}$ & 8 & 48 & 16 & 8 & & 2 & 15 & 3 & & & 82.0 & 6.7 \\
\hline Palm oil ${ }^{3}$ & & 0.2 & 1.1 & 44.2 & 0.2 & 4.4 & 39 & 10.6 & 0.3 & & 50.2 & 0.98 \\
\hline Palm mid fraction ${ }^{4}$ & & & 1.0 & 51.9 & & 5.2 & 36.1 & 5.9 & 1.0 & & 59.1 & 1.3 \\
\hline Cocoa butter Ecuador ${ }^{4}$ & & & & 27.9 & & 33.7 & 34.1 & 3.4 & 1.0 & & 62.6 & 0.74 \\
\hline Shea butter ${ }^{4}$ & & & & 3.5 & & 44.6 & 44.4 & 6.1 & 1.4 & & 49.5 & 0.07 \\
\hline Sunflower hard stearin ${ }^{5}$ & & & & 5.1 & & 50.1 & 38.1 & 0.5 & 2.6 & 3.6 & 61.4 & 0.13 \\
\hline
\end{tabular}

${ }^{1}$ Fernández-Moya et al. (2005); ${ }^{2}$ Salas et al. (2011); ${ }^{3}$ Salas et al. (2009); ${ }^{4}$ Bootello et al. (2012); ${ }^{5}$ Bootello (2012).

blood cholesterol levels, so it can be considered healthier than fats based on palmitic or short chained fatty acids (Hunter et al., 2010). Thus, the atherogenicity index of high stearic sunflower oil is considerably lower than those from palm, coconut or palm kernel fats (Tab. 1). Finally, confectionery fats are usually rich in stearate (Smith, 2021), as in the case of cocoa and shea butters. Thus, high stearic sunflower oil could be a potential source of high stearic high oleic fat embracing a broader variety of applications.

The first high stearic sunflower line isolated displayed $15-20 \%$ stearic acid in a high linoleic background and was named CAS-3. Inheritance of this trait was studied in detail and was found to be partially dominant and produced by two mutations (Pérez-Vich et al., 1999). The one with a large impact on the stearic level was the mutation Es1, which was mapped together with one of genes corresponding to a stearoyl-ACP desaturase ( $S A D)$ from sunflower, named $S A D 17$ (Pérez-Vich et al., 2002). The other mutation enhanced the increase of stearic acid induced by the first and the genes responsible have not been identified. Thus, the Es1 mutation produced a decrease of the intraplastidial SAD activity altering the composition of the acyl-ACP pool, which resulted in large increases in the proportion of stearoyl-ACP. Stearate is then exported out of plastids by the action of acyl-ACP thioesterases, activated into CoA derivatives and incorporated in the TAG synthesis pathway (Salas et al., 2014). The process of export, activation and synthesis of glycerolipids is complex and involves a large number of genes and enzymes with their own specificity and regulation, which will largely determine the capacity of this seed to accumulate stearate in its oil. The mutant seed plastids provide the necessary rates of stearate export to drain the excess of this fatty acid. The export of fatty acids requires the action of acyl-ACP thioesterase enzymes, which hydrolyze the acyl-ACP derivatives allowing the transfer of fatty acids to the cytosol. Sunflower plastids possess a very high thioestearase activity of the FatA type, with high specificity towards oleoyl-ACP, but still able to hydrolize stearoyl-ACP at moderate rates (Serrano-Vega et al., 2005). Sunflower also expresses at lower levels a FatB type thioesterase with specificity for saturated derivatives (Aznar-Moreno et al., 2016, 2018). In vivo labelling studies indicated that high stearic sunflower mutants with high levels of intraplastidial thioesterases are able to accumulate larger amounts of stearic acid (Pleite et al., 2006). Further studies indicated that there are other restrictions to stearate accumulation in sunflower, such as low levels of acyl-CoA synthase or reduced activity of the glycerol-3-phosphate acyltransferase towards stearoyl-CoA, which affects the incorporation and distribution of stearate into sunflower TAGs (Salas et al., 2014; Payá-Milans et al., 2016).

Other high stearic mutants different from CAS-3 have been reported. The CAS-14 mutant can produce higher levels of stearic acid than CAS-3, although the content and distribution of this fatty acid varied along the seed, being maximum at the seed bottom or distal half of the seed and minimum in the apical half of the seed (Fernández-Moya et al., 2002). The trait is strongly dependent on growth temperature: high growing temperatures induced higher proportions of stearate in the oil. The CAS-14 trait was due to a single mutation that affected the expression of both $S A D$ genes expressed in sunflower (Pérez-Vich et al., 2006; Salas et al., 2008).

The original CAS-3 mutant was obtained in a standard linoleic background, but this trait was transferred to high oleic lines giving high stearic-high oleic combinations, which received the name of CAS-15 (Tab. 1, Garcés et al., 2009). These lines can show up to $20 \%$ stearic acid in a very high oleic background. Such fatty acid composition makes the oil from these lines extremely stable, and it has been proved to have high thermal stability (Márquez-Ruiz et al., 1999), which makes it an excellent frying oil, a primary important application for this new fat (Tab. 2). Furthermore, this oil has a great potential as a source of confectionery fats, which are based on stearic and oleic fatty acids. 
Table 2. Applications of high stearic sunflower oil and fractions.

\begin{tabular}{ll}
\hline High oleic-high stearic sunflower oil & High stability frying \\
\hline High oleic-high stearic soft stearins (dry fractionation) & Bakery, margarine hard stock, fat fillings \\
High oleic-high stearic hard stearins (solvent fractionation) & $\begin{array}{l}\text { Cocoa butter equivalent formulation, chocolate compound formulation, } \\
\text { confectionary products, cocoa butter improver }\end{array}$ \\
High oleic high stearic oleins & High stability liquid oil (retailing), high stability frying \\
\hline
\end{tabular}

Although the composition and potential of the high stearic sunflower oils available at present are sufficient to encourage investment in its production and exploitation, some aspects can still be improved in new mutagenesis and breeding programs. A search for new high stearic mutations with a higher level of dominance than those found to date is also essential to develop a better alternative to tropical fats. The new mutations should affect the SAD enzymes involved in the reserve TAG synthesis, with no limitation to plant growth and development, allowing the production of commercial varieties with satisfactory yields.

\section{High stearic sunflower fractionation}

Studies of the biosynthesis and regulation of lipid production in oil crops indicate that accumulation of saturated fatty acids in temperate climate oilseeds such as sunflower, rapeseed or soybean is limited by their adaptation to low temperatures (Salas et al., 2009). In contrast, in tropical climates, higher temperatures permit plants to maintain higher levels of saturated fatty acids in their membranes. This type of biochemical and physiological limitation makes the direct production of plastic fats by temperate oil crops improbable, and this is even more true for production of confectionery fats. A solution for this limitation could be the concentration of the TAGs with a higher level of saturation after oil extraction. This is possible by an industrial process known as "oil fractionation a", which is widely applied to tropical fats, mainly shea butter, palm and palm kernel oils (Timms, 1997; Gibon, 2006). Refined oils are submitted to a first step of crystallization of the high melting point TAGs, followed by separation and concentration of the solid phase formed. The process can be performed by two different methods, with or without addition of a solvent. In solvent fractionation, the oil is blended with a given proportion of solvent to form a micelle before crystallization (Gibon, 2006). Once the micelle is crystallized the stearin produced is filtered under a vacuum and the entrapped olein is removed by washing the cake with fresh solvent. Dry fractionation involves direct crystallization of the oil, followed by press filtration of the stearin and removal of entrapped olein by squeezing at high pressure. The first process is more efficient, can be performed continuously and does not require high pressure equipment. However, fractions have to be distilled to eliminate the solvent and the process requires large volumes of organic solvents (usually hexane or acetone), which considerably increase operational costs. Therefore, solvent fractionation is usually only applied for the production of highly valuable confectionery fats (shea stearin). Dry fractionation is less efficient and involves a discontinuous process (Deffense, 1985). It also requires high pressure filtration equipment but operational costs are reduced and the process can be easily divided into a series of fractionations to produce a variety of products with different properties and melting profiles. The best example of this is the multi-step fractionation of palm oil, which results in the production of palm stearins, palm mid fraction, palm olein and palm superolein.

The possibility of applying these processes to high stearic sunflower would considerably increase its industrial interest so this was widely investigated in earlier projects. Solvent fractionation of high oleic-high stearic sunflower oil was extensively studied at lab scale using oils with different stearate levels (Salas et al., 2011). Stearins highly enriched in TAGs carrying two saturated fatty acids or disaturated TAGs were obtained using both acetone or hexane as solvent. The resulting stearins contained $63.2 \%$ s of 1,3-stearyl-2-oleoyl glycerol (StOSt). Some of these stearins were similar in composition and melting profile to those obtained from shea butter (Tab. 1, Fig. 1), widely used in the formulation of cocoa butter equivalents (CBEs). The effect of solvent and the oil solvent ratio was further studied by Bootello et al. (2015), who indicated that acetone promoted a quick and complete crystallization of disaturated TAGs StOSt and 1(3)-palmitoyl-3(1)-stearoyl-2-oleoyl glycerol (POSt) using oil solvent/ ratios from $1 / 1$ to $1 / 4$ and applying fractionation temperatures between 5 and $15^{\circ} \mathrm{C}$. Fractionation with hexane required higher oil-to-solvent ratios and lower temperatures, providing stearins with very high contents of disaturated TAGs, although their recovery from the initial oils were reduced due their higher solubility in that solvent. The final conclusion of that work is that acetone was an appropriate solvent for a process requiring the maximum yield of stearins with a high content of solids using moderate crystallization temperatures. Hexane fractionation appeared more appropriate for the preparation of special samples with very high content of disaturated TAGs. The butters resulting from solvent fractionation of high stearic sunflower oil were characterized as components of CBEs and confectionery fats. CBEs, by definition, are fats with compositions and crystallization behaviors similar to $\mathrm{CB}$ and fully compatible with it in blends at any proportion (Lipp and Anklam, 1998). CBEs are used in many types of confectionery formulations and in some countries, they can be blended up to a limit of $5 \%$ in chocolates and chocolate compounds. CBEs based on different sunflower hard stearins were formulated according to their phase behaviour diagrams and their solid fat content data at $25^{\circ} \mathrm{C}$. Their properties were studied and compared with a reference $\mathrm{CBE}$ formulated with shea stearin. The CBEs from sunflower stearin displayed melting curves similar to that of the reference and exhibited no eutectics in blends with $\mathrm{CB}$, so it was concluded they were 


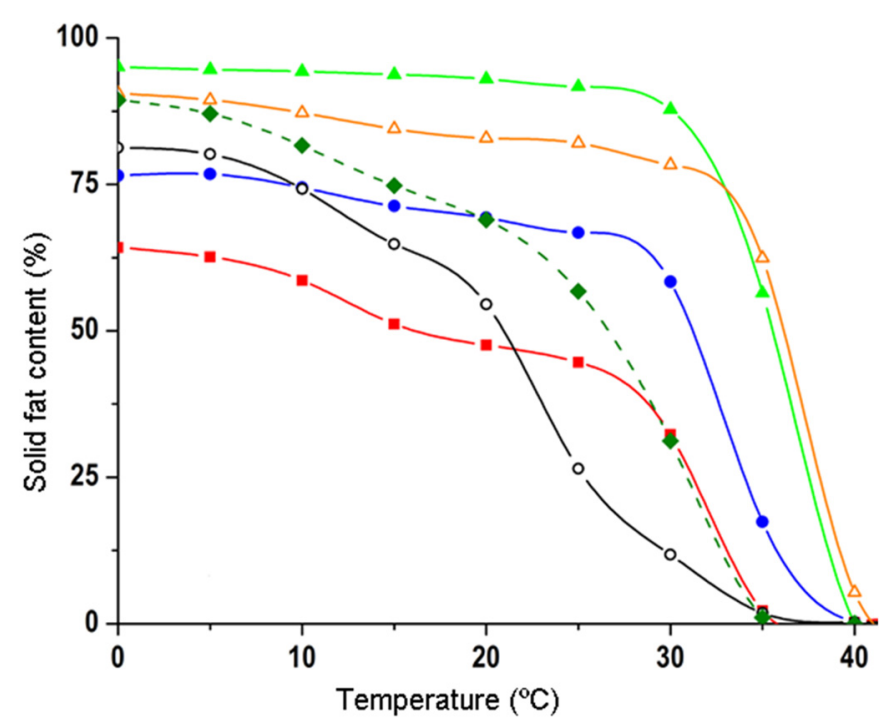

Fig. 1. Some examples of solid fat content curves of oils and fractions obtained from high stearic sunflower oil by solvent fractionation and some commercial tropical butters. (_- $)$ Cocoa butter; (- $\left.\bigcirc_{-}\right)$palm mid fraction; (- $\left.\triangle_{-}\right)$shea stearin; (- $\left.\Delta_{-}\right)$sunflower stearin (95\% SUS); (-๑) sunflower stearin (80\% SUS); (-ם-) sunflower stearin (65\% SUS). Data taken from Bootello et al. (2012). SUS: disaturated triacylglycerols.

appropriate for the formulation of compounds and confectionery fats (Bootello et al., 2012, 2013). In a later study, CBEs from sunflower stearins were tested as the base ingredient of chocolate compounds and its performance was compared with that obtained from commercial CBE formulations. Milk chocolate and some coating compounds made with them were characterized in terms of microstructure, thermal stability and hardness. The changes in crystalline structure and bloom development were also investigated. The microstructure of sunflower-based compounds was more compact than that produced by CB or commercial CBEs (Bootello et al., 2018). Sunflower based CBEs provided more solids with less saturated fatty acids and studies of crystallization kinetics indicated that it was tempered faster than milk chocolate. Therefore, the use of sunflower stearins in the formulation of chocolate compounds could improve the tempering process by speeding up crystallization into more stable polymorphs and reducing e processing costs with shorter storage time (Tab. 2). Nevertheless, the production of hard sunflower stearins by solvent fractionation is at present limited by the low content of stearic acid in oil from commercial sunflower hybrids, giving low yields of stearin compared with the high operation costs inherent to this process. The production of hard stearins can be performed more efficiently from fractions with higher levels of stearate, such as the stearins that can be obtained by dry fractionation.

\section{New techniques of fractionation}

Dry fractionation of high stearic sunflower oil is a method permitting production of fractions with high levels of saturated

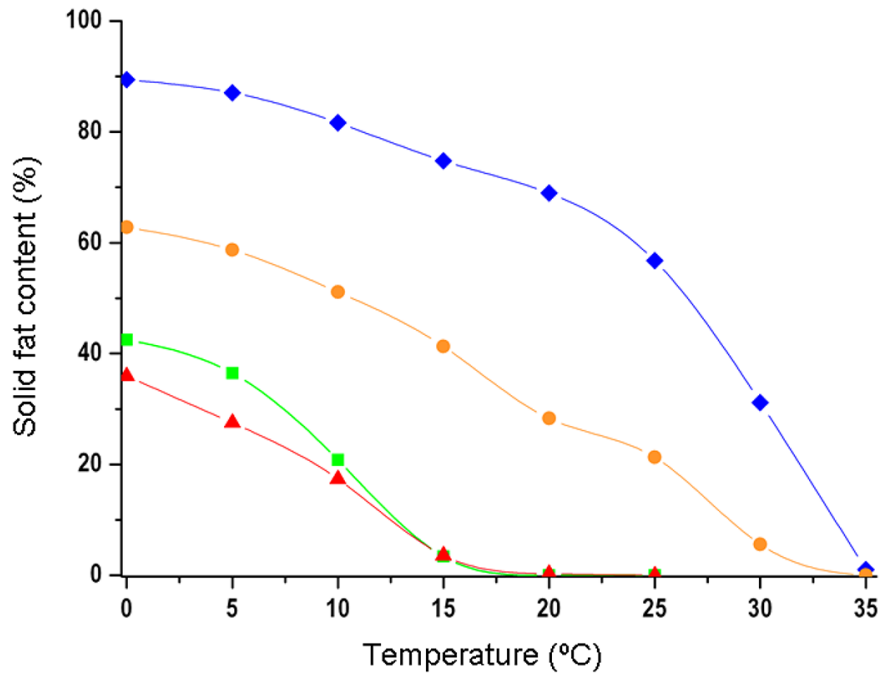

Fig. 2. Solid fat content curves of some fractions, oils and butters. (- - ) Sunflower high stearic oil; (-๑) high stearic sunflower stearin obtained by dry fractionation; (- $\left.\boldsymbol{\Delta}_{-}\right)$high stearic sunflower olein resulting from dry fractionation; (- $)$ cocoa butter. Data taken from Bootello et al. (2012).

fatty acids and high yields of solid content but at lower costs than solvent methods (Gibon, 2006). Dry fractionation involves TAG crystallization, filtration of the resulting slurry and squeezing the filtrate at high pressure. This procedure requires specific equipment allowing pressures up to 30 bars and involves work in batches (Deffense, 1985). Crystallization of the oil is the most important step in this process, since large well-formed crystals that can be easily filtered and squeezed are required; small crystals can clog the filter medium making difficult or impossible separation and conditioning of the solid phase. Dry fractionation of high stearic sunflower has been thoroughly investigated at lab, pilot plant and industrial scales (Bootello et al., 2011, 2012). The stearin fractions that resulted had lower saturated fatty acid levels than those obtained by solvent fractionation, with profiles of solid fat content appropriate for their use as plastic fats in bakery, margarine and spread formulation (Fig. 2). These trials indicated that the process is limited and hampered by two characteristics of this oil; the presence of long wax esters and the distribution of saturated fatty acids in the oil TAGs (Bootello et al., 2014). Unlike other vegetable oils, sunflower oils contain long chain wax esters that crystallize at room temperature causing turbidity and increasing viscosity (Broughton et al., 2018), regular sunflower oils are usually winterized before commercialization. Since high stearic sunflower oil has to be cooled down for TAG crystallization, the process also involves the crystallization of wax esters. Trials at different scales demonstrated that crystallized wax esters hampered the crystallization and filtration of TAGs, decreasing filtration rates and at worst clogging the filtration medium (Bootello et al., 2014). Partial dewaxing of the oil at temperatures higher than those applied for regular sunflower oil clarification and filtration with filter aid is necessary to avoid the negative effect of wax esters. Studies of crystallization kinetics for this oil indicated that the process was more controllable and repetitive when crystal seeding was applied. This changed the 
crystallization pattern and improved stearin characteristics. Seeding can use powder of some high melting point butter (cocoa butter or shea stearin) at about $0.25 \%$ (Bootello et al., 2011). The distribution of saturated fatty acids is highly asymmetrical in high stearic sunflower oil, and the presence of TAGs with a single saturated fatty acid esterified or monosaturated TAGs of the type StOO is favoured against the disaturated ones, which are more easily crystallizable (Martínez-Force et al., 2004). This means that the level of disaturated TAGs can vary significantly depending on the stearic acid content of the oil. Industrial extraction of typical high stearic sunflower oils yields 10 to $16 \%$ of stearin. These stearins contain between 30 to $40 \%$ of disaturated TAGs and only traces of trisaturated ones, and so constitute plastic fats with applications in baking, fillings and margarine formulation (Tab. 2, Bootello et al., 2011). The liquid fraction resulting from this process is an oil containing high levels of oleic and stearic acids in the form of diunsaturated TAGs, making it stable and liquid at room temperature and appropriate for frying and retailing (Tab. 2, Salas et al., 2007).

As discussed above, dry fractionation of high stearic sunflower oils needs to overcome some challenges, making it more difficult to implement than the fractionation of other oils like palm or palm kernel. Recent research focused on resolution of these problems by developing new processing and fractionation techniques. This involves interesterification of sunflower oils prior to fractionation. Interesterification can be either enzymatic or chemical, and provides interesterified (IE) oils with identical fatty acid composition but different TAG conformation. The randomization of fatty acids along the 3 glycerol positions of TAGs induced the formation of trisaturated TAGs such as tristearin and the presence of some stearic acid in the sn-2 position of glycerol. It also increased the content of disaturated TAGs that included SSU and SUS forms. The fractionation of IE oils was shown to be much more less problematic than that observed for native oils: the oil crystallized easily, there was no interference of wax esters and seeding was not necessary. Furthermore, the fractionations can be performed at lower temperatures, which together with the increase of disaturated and trisaturated TAGs resulted in 25 to $35 \%$ increases in stearin yields, and more than $30 \%$ for disaturated TAGs. The method also allowed fractionation of oils with lower stearate contents, and oils with higher levels of linoleic acid, producing stearins with high levels of solids that can be used as plastic fats. These stearins and the production method were protected by a recently filed patent (Piispa et al., 2019).

\section{Conclusion}

In summary, high stearic sunflower was conceived as a healthy alternative to tropical fats. but commercial production of high melting point fats from sunflower have required considerable research and development involving the production of varieties with higher and improved distribution of stearate in the TAGs. Processing of these oils for the production of fractions with specific applications (Tab. 2) has been also developed, with significant advances recently that bring closer the objective of large scale production of plastic and confectionery fats from local production in temperate countries.

\section{References}

Alberio C, Aguirrezábal LA, Izquierdo NG, Reid R, Zuil S, Zambelli A. 2018. Effect of genetic background on the stability of sunflower fatty acid composition in different high oleic mutations. J Sci Food Agric 98: 4074-4084. https://doi.org/10.1002/jsfa.8924.

Aznar-Moreno JA, Venegas-Calerón M, Martínez-Force E, Garcés R, Salas JJ. 2016. Acyl carrier proteins from sunflower (Helianthus annuus L.) seeds and their influence on FatA and FatB acyl-ACP thioesterase activities. Planta 244: 479-490. https://doi.org/ 10.1007/s00425-016-2521-7.

Aznar-Moreno JA, Sánchez R, Gidda SK, et al. 2018. New insights into sunflower (Helianthus annuus L.) FatA and FatB thioesterases, their regulation, structure and distribution. Front Plant Sci 9: 1496-1510. https://doi.org/10.3389/fpls.2018.01496.

Bockisch M. 2015. Fats and oils handbook. Cambridge, Massachusetts: Academic Press and AOCS Press. ISBN 9780981893600.

Bootello MA. 2012. High stearic high oleic oil: fractionation and fraction characterization. Doctoral Thesis, University of Sevilla.

Bootello MA, Garcés R, Martínez-Force E, Salas JJ. 2011. Dry fractionation and crystallization kinetics of high-oleic highstearic sunflower oil. J Am Oil Chem Soc 88: 1511-1519. https:// doi.org/10.1007/s11746-011-1827-7.

Bootello MA, Hartel RW, Garcés R, Martínez-Force E, Salas, JJ. 2012. Evaluation of high oleic-high stearic sunflower hard stearins for cocoa butter equivalent formulation. Food Chem 134: 1409-1417. https://doi.org/10.1016/j.foodchem.2012.03.040.

Bootello MA, Hartel RW, Levin M, et al. 2013. Studies of isothermal crystallisation kinetics of sunflower hard stearin-based confectionery fats. Food Chem 139: 184-195. https://doi.org/10.1016/j. foodchem.2012.11.141.

Bootello MA, Garcés R, Martínez-Force E, Salas JJ. 2014. The role of waxes in the dry fractionation of high oleic-high stearic sunflower oil. In: 12th EuroFedLipid Congress (2014), Montpellier, France (poster contribution).

Bootello MA, Garcés R, Martínez-Force E, Salas JJ. 2015. Effect of solvents on the fractionation of high oleic-high stearic sunflower oil. Food Chem 172: 710-717. https://doi.org/10.1016/j.food chem.2014.09.136.

Bootello MA, Chong PS, Máñez A, Garcés R, Martínez-Force E, Salas JJ. 2018. Characterization of sunflower stearin-based confectionery fats in bulk and in compound coatings. J Am Oil Chem Soc 95: 1139-1150. https://doi.org/10.1002/aocs.12126.

Broughton R, Ruíz-Lopez N, Hassall KL, et al. 2018. New insights in the composition of wax and sterol esters in common and mutant sunflower oils revealed by ESI-MS/MS. Food Chem 269: 70-79. https://doi.org/10.1016/j.foodchem.2018.06.135.

Deffense E. 1985. Fractionation of palm oil. J Am Oil Chem Soc 62: 376-385. https://doi.org/10.1007/BF02541408.

Dijstra A. Oil refining. In: Martínez-Force E, Dunford NT, Salas JJ, eds. Sunflower: chemistry, production, processing, and utilization. Urbana (USA): AOCS Press, 2015, pp. 227-258.

FAO. 2020. Oil crops oils and meals market assessments. www.fao.org.

FAO/WHO technical reports series. 2002. Diet, nutrition and the prevention of chronic diseases. www.fao.org/3/AC911E/AC911E00.htm.

Fernández-Martínez JM, Jimenez A, Dominguez J, Garcia JM, Garces R, Mancha M. 1989. Genetic analysis of the high oleic acid content in cultivated sunflower (Helianthus annuus L.). Euphytica 41: 39-51. https://doi.org/10.1007/BF00022409.

Fernández-Martínez JM, Mancha M, Osorio J, Garcés R. 1997. Sunflower mutant containing high levels of palmitic acid in high oleic background. Euphytica 97: 113-116. https://doi.org/ 10.1023/A:1003045726610. 
Fernández-Moya V, Martínez-Force E, Garcés R. 2002. Temperature effect on a high stearic acid sunflower mutant. Phytochem 59: 33 37. https://doi.org/10.1016/S0031-9422(01)00406-X.

Fernández-Moya V, Martínez-Force E, Garcés R. 2005. Oils from improved high stearic acid sunflower seeds. J Agric Food Chem 53: 5326-5330. https://doi.org/10.1021/jf0503412.

Garcés R, Martínez-Force E, Salas JJ, Venegas-Calerón M. 2009. Current advances in sunflower oil and its applications. Lipid Tech 21: 79-82. https://doi.org/10.1002/lite.200900016.

Ghotra BS, Dyal SD, Narine SS. 2002. Lipid shortenings: a review. Food Res Int 35: 1015-1048. https://doi.org/10.1016/S0963-9969 (02)00163-1.

Gibon V. Fractionation of lipids for use in food. In: Gunstone FD, ed. Modifying lipids for use in food. Boca Ratón (USA): CRC Press, 2006, pp. 201-233.

Gunstone FD. 2009. Oils and fats in the food industry. Oxford, UK: Wiley-Blackwell. ISBN-10:1-4051-7121-9.

Hongtrakul V, Slabaugh MB, Knapp SJA. 1998. Seed specific $\Delta$-12 oleate desaturase gene is duplicated, rearranged, and weakly expressed in high oleic acid sunflower lines. Crop Sci 38: 1245-1249. https://doi. org/10.2135/cropsci1998.0011183x003800050022x.

Hunter JE, Zhang J, Kris-Etherton PM. 2010. Cardiovascular disease risk of dietary stearic acid compared with trans, other saturated, and unsaturated fatty acids: a systematic review. Am J Clin Nutr 91: 46-63. https://doi.org/10.3945/ajcn.2009.27661.

Kellens M, Gibon V, Hendrix M, De Greyt W. 2007. Palm oil fractionation. Eur J Lipid Sci Tech 109: 336-349. https://doi.org/ 10.1002/ejlt.200600309.

Kleingartner LW. NuSun sunflower oil: redirection of an industry. In: Janick J, Whipkey A, eds. Trends in new crops and new uses. Alexandria (USA): ASHS Press, 2002, pp. 135-138.

Lacombe S, Bervillé A. 2001. A dominant mutation for high oleic acid content in sunflower (Helianthus annuus L.) seed oil is genetically linked to a single oleate-desaturase RFLP locus. Mol Breed 8: 129-137. https://doi.org/10.1023/A:1013358711651.

Lacombe S, Abbott AG, Bervillé A. 2002a. Repeats of an oleate desaturase region cause silencing of the normal gene explaining the high oleic pervenets sunflower mutant. Helia 25: 95-104. https://doi.org/10.2298/hel02360951.

Lacombe S, Léger S, Kaan F, Bervillé A. 2002b. Inheritance of oleic acid content in $\mathrm{F} 2$ and a population of recombinant inbred lines segregating for the high oleic trait in sunflower. Helia 25: 85-94. https://doi.org/10.2298/he102360851.

Le Clef E, Kemper T. Sunflower seed preparation and oil extraction. In: Martínez-Force E, Dunford NT, Salas JJ, eds. Sunflower: chemistry, production, processing, and utilization. Urbana (USA): AOCS Press, 2015, pp. 187-226.

Lipp M, Anklam E. 1998. Review of cocoa butter and alternative fats for use in chocolate. Food Chem 62: 73-99. https://doi.org/ 10.1016/S0308-8146(97)00160-X.

Márquez-Ruiz G, Garcés R, León-Camacho M, Mancha M. 1999. Thermoxidative stability of triacylglycerols from mutant sunflower seeds. J Am Oil Chem Soc 76: 1169-1174. https://doi.org/ 10.1007/s11746-999-0091-6.

Martínez-Force E, Ruiz-López N, Garcés R. 2004. The determination of the asymmetrical stereochemical distribution of fatty acids in triacylglycerols. Anal Biochem 334: 175-182. https://doi.org/ 10.1016/j.ab.2004.07.019.

Martínez-Rivas, JM, Sperling, P, Lühs, W, Heinz, E. 2001. Spatial and temporal regulation of three different microsomal oleate desaturase genes (FAD2) from normal-type and high-oleic varieties of sunflower (Helianthus annuus L.). Mol Breed 8: 159-168. https://doi.org/10.1023/A:1013324329322.
Martín-Polvillo M, Márquez-Ruiz G, Dobarganes, MC. 2004. Oxidative stability of sunflower oils differing in unsaturation degree during long-term storage at room temperature. J Am Oil Chem Soc 81: 577583. https://doi.org/10.1007/s11746-006-0944-1.

Osorio J, Fernández-Martínez J, Mancha M, Garcés R. 1995. Mutant sunflowers with high concentration of saturated fatty acids in the oil. Crop Sci 35: 739-742. https://doi.org/10.2135/crops ci1995.0011183x003500030016x.

Parkash Kochhar S, Gertz C. 2004. New theoretical and practical aspects of the frying process. Eur J Lipid Sci Tech 106: 722-727. https://doi.org/10.1002/ejlt.200400996.

Payá-Milans M, Aznar-Moreno JA, Balbuena TS, et al. 2016. Sunflower HaGPAT9-1 is the predominant GPAT during seed development. Plant Sci 252: 42-52. https://doi.org/10.1016/j. plantsci.2016.07.002.

Pérez-Vich B, Garcés R, Fernández-Martínez JM. 1999. Genetic control of high stearic acid content in the seed oil of the sunflower mutant CAS-3. Theor App Gen 99: 663-669. https://doi.org/ $10.1007 / \mathrm{s} 001220051282$.

Pérez-Vich B, Fernandez-Martinez JM, Grondona M, Knapp SJ, Berry ST. 2002. Stearoyl-ACP and oleoyl-PC desaturase genes cosegregate with quantitative trait loci underlying high stearic and high oleic acid mutant phenotypes in sunflower. Theor App Gen 104: 338-349. https://doi.org/10.1007/s001220100712.

Pérez-Vich B, Leon AJ, Grondona M, Velasco L, Fernández-Martínez JM. 2006. Molecular analysis of the high stearic acid content in sunflower mutant CAS-14. Theor App Gen 112: 867-875. https:// doi.org/10.1007/s00122-005-0188-8.

Piispa E, Bootello MA, Hornyak L, Salas JJ, Martinez-Force E, Garces R. 2019. New high stearic oilseed stearin fat and process for its preparation. WO2019166598A1.

Pleite R, Martínez-Force E, Garcés R. 2006. Increase of the stearic acid content in high-oleic sunflower (Helianthus annuus L.) seeds. J Agric Food Chem 54: 9383-9388. https://doi.org/ 10.1021/jf061654f.

Salas JJ, Martínez-Force E, Garcés R. 2007. Liquid and stable olein fractions. WO2008006597A2.

Salas JJ, Youssar L, Martínez-Force E, Garcés R. 2008. The biochemical characterization of a high-stearic acid sunflower mutant reveals the coordinated regulation of stearoyl-acyl carrier protein desaturases. Plant Physiol Biochem 46: 109-116. https:// doi.org/10.1016/j.plaphy.2007.10.007.

Salas JJ, Bootello MA, Martínez-Force E, Garcés R. 2009. Tropical vegetable fats and butters: properties and new alternatives. $O C L$ 16: 254-258. https://doi.org/10.1051/ocl.2009.0278.

Salas JJ, Bootello MA, Martínez-Force E, Garcés R. 2011. Production of stearate-rich butters by solvent fractionation of high stearichigh oleic sunflower oil. Food Chem 124: 450-458. https://doi. org/10.1016/j.foodchem.2010.06.053.

Salas JJ, Martínez-Force E, Harwood JL, et al. 2014. Biochemistry of high stearic sunflower, a new source of saturated fats. Prog Lipid Res 55: 30-42. https://doi.org/10.1016/j.plipres.2014.05.001.

Salas JJ, Bootello MA, Garcés R. Food uses of sunflower oils. In: Martínez-Force E, Dunford NT, Salas JJ, eds. Sunflower: chemistry, production, processing, and utilization. Urbana (USA): AOCS Press, 2015, pp. 441-464.

Serrano-Vega MJ, Garcés R, Martinez-Force E. 2005. Cloning, characterization and structural model of a FatA-type thioesterase from sunflower seeds (Helianthus annuus L.). Planta 221: 868880. https://doi.org/10.1007/s00425-005-1502-z.

Smith KW. Cocoa butter and cocoa butter equivalents. In: Gunstone FD, ed. Structured and modified lipids. New York (USA): CRC Press, 2001, pp. 401-422. 
Smith KW. Confectionery fats. In: Garti N, Widlak NR, eds. Cocoa butter and related compounds. Urbana (USA): AOCS Press, 2021, pp.475-495. https://doi.org/doi.org/10.1016/ C2015-0-02409-1.

Soldatov KI. 1976. Chemical mutagenesis in sunflower breeding. In: Proc. 7th Int. Sunflower Association Vlaardingen, The Netherlands, pp. 352-357.

Sperling P, Hammer U, Friedt W, Heinz E. 1990. High oleic sunflower: studies on composition and desaturation of acyl groups in different lipids and organs. Z Naturforschung C 45: 166-172. https://doi.org/10.1515/znc-1990-3-405.

Subar, AF, Krebs-Smith SM, Cook A, Kahle LL. 1998. Dietary sources of nutrients among US adults, 1989 to 1991. J Am Dietetic Assoc 98: 537-547. https://doi.org/10.1016/S0002-8223(98)00122-9.
Talbot G. Fats for confectionery coatings and fillings. In: Talbot G, ed. Science and technology of enrobed and filled chocolate, confectionery and bakery products. Boca Raton (USA): CRC-Press, 2009, pp. 53-79. https://doi.org/10.1533/9781845696436.1.53.

Timms RE. Fractionation. In: Gunstone FD, ed. Lipid technologies and applications. New York (USA): Marcel Dekker Inc., 1997, pp. 199-222.

Traitler H, Dieffenbacher A. 1985. Palm oil and palm kernel oil in food products. J Am Oil Chem Soc 62: 417-421. https://doi.org/ 10.1007/BF02541414.

Zhang Z, Lee WJ, Wang Y. 2020. Evaluation of enzymatic interesterification in structured triacylglycerols preparation: a concise review and prospect. Crit Rev Food Sci Nutr 62: 1-15. https://doi.org/10.1080/10408398.2020.1793725.

Cite this article as: Salas JJ, Bootello MA, Martínez-Force E, Venegas Calerón M, Garcés R. 2021. High stearic sunflower oil: Latest advances and applications. OCL 28: 35 . 